\title{
Quality of the ISO 9000 series of standards-perceptions of quality management experts
}

\author{
Piotr Rogala \\ Department of Quality and Environmental Management, \\ Wroclaw University of Economics and Business, Wroclaw, Poland, and \\ Slawomir Wawak \\ Department of Management Process, Cracow University of Economics, Krakow, Poland
}

\section{Quality management experts}

Received 30 April 2020 Revised 31 August 2020 Accepted 8 January 2021

\begin{abstract}
Purpose - The authors of this study, who adopted a holistic view of the international organization for standardization (ISO) 9000 series of standards, aimed to evaluate the current status of the standards within the framework of the quality movement. Specifically, the evaluation covered two dimensions, i.e. the significance of the content included in the standards and the quality of the standards' elaboration, which encompasses such issues as, for instance, their correctness, relevance to current trends in quality management, comprehensibility, etc.

Design/methodology/approach - The paper is based on a review of the scientific literature, analysis of the current and all previous versions of the international standards and the results of a survey, through which data were collected from 73 quality management experts from 17 different countries. To evaluate the results, an importance-performance analysis was performed.

Findings - As the results of the research demonstrated, experts in quality management have accepted the ISO 9000 standards series. However, this positive view refers mainly to the very idea of developing quality management standards and these standard's content structure (components included in them). Study participants assigned a low rating to the quality of the standards' elaboration. Therefore, improving the following aspects of the standards is essential: definitions, guidelines explaining the requirements for a quality management system, self-assessment tools and guidelines concerning quality management concerning chosen forms of activity.

Research limitations/implications - The research described here in has both practical and social implications. First, it delineates the direction needed to improve standardizations, whose use need not be strictly limited to quality management but can be successfully used to improve the standards in other areas of management. Therefore, the conclusions of this research directly contribute to increasing both the effectiveness and the quality of the standard organizations. The significant consequences of this research for managers are the identification of ISO 9000 components which they will find are the most useful.

Practical implications - The research described herein has both practical and social implications. First, it delineates the direction needed to improve standardizations, whose use need not be strictly limited to quality management. However, it can be successfully used to improve the standards in other areas of management. Therefore, the conclusions of this research directly contribute to increasing both the effectiveness and the quality of the standard organizations. The significant consequences of this research for managers are the identification of ISO 9000 components, which they will find are the most useful.
\end{abstract}

(C) Piotr Rogala and Slawomir Wawak. Published by Emerald Publishing Limited. This article is published under the Creative Commons Attribution (CC BY 4.0) licence. Anyone may reproduce, distribute, translate and create derivative works of this article (for both commercial and noncommercial purposes), subject to full attribution to the original publication and authors. The full terms of this licence maybe seen at http://creativecommons.org/licences/by/4.0/legalcode

Declaration of interest: None.

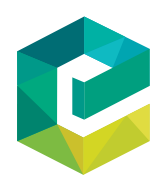

International Journal of Quality and Service Sciences Vol. 13 No. 4,2021 pp. 509-525 1756-669X DOI 10.1108/IJQSS-04-2020-0065 
IJQSS

13,4

510

Originality/value - Most research treats ISO 9000 standards as a benchmark for their studies on quality management systems implemented in organizations. The standards themselves are rarely the subject of a study, and so this paper fills a gap in the research and provides insights into desired directions for standards improvement.

Keywords ISO 9000, ISO 9001, ISO 9004, Quality management, Quality movement, Importance-performance analysis

Paper type Research paper

\section{Introduction}

In 1997, Seddon was highly critical of international quality management standards. Among other standards, he asserted that "ISO 9000 has only succeeded in steering quality into troubled waters. Far from being the first step to quality, it has been a step in the wrong direction" (Seddon, 1997).

A total of 23 years have elapsed, as that moment and much has changed. The standards have undergone several revisions, the number of ISO 9001 certified organizations has increased to nearly five times its size during Seddon's time (www.iso.org) and new standards concerning quality management and other subjects (e.g. occupational health and safety, energy and human resources) have been instituted. Moreover, numerous scientific studies have been conducted on ISO 9000 series of standards and the focus of researchers has been issues related to procedures for the successful implementation of a quality management system and the benefits of this implementation. This limitation is unjustified, primarily because it omits or depreciates the significance of ISO 9000 series standards other than those dedicated to quality management, a situation John West describes as follows:

I have observed that awareness of the existence of these and other guidance documents by users seems to be declining. While my data is certainly anecdotal, I find that most new users and even a number of "ISO consultants" I have met are unaware of their existence. And the lack of awareness extends to supporting standards, not just free guidance. And there is plenty of other free guidance available as well! There is a great deal of richness in the ISO 9000 family of documents and it is a shame for users not to know about and take advantage of the full range of possibilities (West, 2007).

What West describes is indeed happening, even though the International Organization for Standardization, in its publications and through its representatives, clearly states that the entire body of standards should be instituted all together and at the same time. Cary Cort (Chair of ISO/TC 176) claimed the following:

I believe we must look beyond individual standards and acknowledge the pre-eminence of a dynamic web of interconnected, mutually supporting standards, guidelines and associated collateral that collectively enable and sustain the ISO 9000 family of standards. I call this interdependent network the ISO 9000 ecosystem, and its primary focus is to create a compelling value proposition for the front-line users and potential users of the ISO 9000 family of standards (Cort, 2010).

On the other hand, it should be remembered that some researchers question the quality and usefulness of international standards. For example, Spring (2016), stated as follows:

Many would like to believe that standards are managed in a coherent and logical way. Indeed, some management and coordination efforts (. . .) have met with success. Many other standards arise [...] as the result of needs that are far less planned.

Based on the above-stated information, the following problems can be identified:

- What is the current status of the ISO 9000 family of standards (regarded as a whole) in the quality management movement framework? 
- Are these standards widely accepted and recognized among specialists dealing with quality management?

- Are these standards viewed as a valued and important part of the quality management concept? Do they reflect modern trends in management?

\section{Quality management experts}

- Do these standards constitute a consistent and useful approach?

To attempt to answer these questions, this research sought to evaluate the quality of the ISO 9000 family of standards, and evaluation that covers two dimensions. The first is the significance of the content included in certain standards. Specifically, this research sought to determine whether separate components of the standards (i.e. those distinguishable on the basis of their content) are significant enough to be included in the standards even if not properly elaborated. The second dimension is the standards' elaboration quality, which takes into consideration such issues as, e.g. their correctness, relevance to current trends in quality management and comprehensibility. To gather this information, we administered a carefully prepared questionnaire to experts in quality management and in ISO 9000. This questionnaire was designed specifically to gather the expert opinions of the respondents, whose recruitment is described below, to answer the following research questions:

$R Q 1$. Is the ISO 9000 family of standards a generally accepted part of the quality movement?

RQ2. Which components of the ISO 9000 family are viewed as the most significant?

RQ3. Which components of the ISO 9000 family are viewed as being elaborated best?

RQ4. Which components of the ISO 9000 family should be improved first?

The search for answers to these questions is justified by the literature. According to Hoel and Chen (2018), there is a need to maintain feedback loops between standardization and scientific research. Standards-making (and improving) should be based on research results, but on the other hand, standards should be the subject of scientific evaluation.

Different methodologies were used to carry out the research needed to answer these questions: a review of the relevant literature, analysis of the current and all previous versions of the ISO 9000 series of standards, a survey (i.e. computer-assisted web interviews - CAWI) and an importance-performance analysis (IPA).

The structure of this paper is as follows: Section 2 reviews the relevant literature to present the background of the study and Section 3 describes the methods used to carry out the study, including defining the data-collection instrument, sampling and conducting the IPA technique. Section 4 identifies the most relevant results of the survey. Finally, Sections 5 and 6 present the discussion, recommendations for future research and implications of the study.

\section{Literature review}

Scholars have studied the quality management system based on ISO 9001, as the publication of its first version in 1987. As then, hundreds of studies have been conducted to examine the effects of the standard's application on enterprises, banks, public administration offices and other organizational types. Moreover, systematic literature reviews that investigated the most critical problems related to the ISO 9000 series of standards have been collected and analyzed. For example, Sampaio et al. (2009) analyzed over 100 articles, finding that the primary issues addressed were the following: evolution of the certification market; the benefits, barriers and drawbacks associated with implementation; the impact of 
IJQSS

13,4

implementation on organizations; and the organizations' financial performance following implementation.

Although some authors proposed additional topics deserving more in-depth analysis, none of these evaluated the standard itself. For instance, Tarí et al. (2012) studied 82 papers on ISO 9001, identifying the 13 most common benefits of instituting the standards that were analyzed by scholars, including improvements in market share, sales, profitability, image, efficiency and customer satisfaction. According to the research results, the scope of these benefits decreased as the number of certified enterprises increased (thereby decreasing the effects of competitive advantage). The studies conducted by Casadesus, Karapetrovic, et al. clearly exhibit this pattern; the range of benefits obtained by the large sample of enterprises the authors analyzed decreased in the years 1998-2006 (Casadesus and Gimenez, 2000; Casadesus and Karapetrovic, 2005; Karapetrovic et al., 2010).

Another relevant field of study has been the organizational effectiveness of management systems based on the ISO 9001 standard. Boiral (2012) reviewed 111 papers on internal benefits, including those impacting effectiveness and efficiency. The author found that multiple benefits could be linked not to ISO 9001 but rather to other phenomena occurring simultaneously. Based on a systematic review, the author presented 46 variables related to both organizational effectiveness and ISO 9001 requirements.

Addressing the controversy surrounding the impact of ISO 9001 standards on product innovation, Manders et al. (2016) reviewed 29 studies, concluding that multiple factors, including sector, region, company size and impact innovation, were responsible for organizations' health, making the impact of ISO 9001 adherence unclear. As the results of the systematic literature reviews discussed above show, unambiguously positive effects of ISO 9001 implementation become increasingly difficult to identify with the passage of time. Saraiva et al. (2017) studied research papers concerning motivations, benefits and difficulties associated with the implementation and certification of quality management systems based on ISO 9001 requirements. They also found that type of benefits, and the degree to which they are exhibited, to be subject to multiple factors. Moreover, Serhan and Kabèche (2017) drew attention to the so-called "ISO 9001 Paradox," which attempts to combine conformity and innovation. Kafel and Nowicki (2014) reported a high cost of ISO 9001 quality management certification causing organizations to withdraw from these certifications.

As the analysis of systematic literature reviews shows, most authors treat ISO 9001 standards as a starting point for their research. They assume that the standard is a model to which an organization's functions should be adjusted. ISO 9001 is treated as a kind of framework for achieving a variety of strategically essential results, namely, profit growth, income growth, customer loyalty and organization image (Urban, 2012). Although this assumption is not explicitly formulated in most of those studies, it is nonetheless assumed and has important implications. The limits of the standards are often discussed in scientific conferences in the field of quality management. Meanwhile, only a few researchers have assessed the ISO 9001 itself. The versions of the standard published in 1987 and 1994 were subject to more criticism (Seddon, 2000; Hallström, 2004) and the 2000 version represented a significant step forward that eliminated most of the weaknesses present in previous versions. However, in a constantly changing business environment, standards should be updated regularly to best suit organizational needs and 2000, 2008 and 2015 versions served this purpose.

However, the question often arises as to whether changes introduced in these versions were sufficient. Gotzamani's (2010) investigation into the effects organizations experience when they update their quality management systems to be consistent with ISO 9001:2000 requirements revealed that the 2000 revision achieved most of its goals, including those 
related to leadership, process management, customer focus and continuous improvement. Gutiérrez et al. (2010) used a different approach, comparing the results achieved by companies resulting from the implementation of ISO 9001, the EFQM model and Six Sigma. Based on the quantitative analysis of 234 organizations, they found that the EFQM model requires increased teamwork, whereas Six Sigma requires increases in support by top management, in process management and in statistical process control compared to ISO 9001. Thus, these authors indicated possible directions for improving the standard. Fonseca and Domingues (2017) asked experienced auditors to evaluate the assumption that ISO 9001:2015 is in line with modern business and quality management concepts and statistical analysis of surveys returned by 393 auditors confirmed that assumption. Unfortunately, the paper did not include a detailed analysis of ISO 9001:2015 requirements. Analyzing how changes in the 2015 release impacted enterprises that implemented or updated their quality management systems, Anttila and Jussila (2017) pointed out that the pace of change in the standards is significantly slower than those in a typical business environment and in society in general, a conclusion that contradicted previously presented research results.

It should be noted that the research methodology, scientific rigor and attitude of researchers have an impact on their research results. In particular, rationalization of actions undertaken by enterprises and the business interests of auditors may render results too optimistic. Therefore, research concerning ISO standards should be carried out using a methodology capable of providing objective results.

\section{Methodology}

This study used a quantitative methodology and used sample surveys, a basic research method commonly used in the social sciences and an important tool in applied work (Wright and Marden, 2010), to gather the necessary information from the study's respondents. The survey was administered to these respondents through CAWI and IPA was used to analyze the collected information.

\subsection{Questionnaire}

The questionnaire used to gather data from study participants was based on a content analysis of current and all previous revisions of the ISO 9000 series. The analysis aimed to identify the key components of the standards.

As far as the terminology standard was concerned, five components of the type were identified (Table 1).

\begin{tabular}{|c|c|c|c|c|c|c|c|}
\hline No. & $\begin{array}{l}\text { Label } \\
\text { Year of publication }\end{array}$ & $\begin{array}{l}\text { ISO } 8402 \\
1986\end{array}$ & $\begin{array}{l}\text { ISO } 8402 \\
1994\end{array}$ & $\begin{array}{l}\text { ISO } 9000 \\
2000\end{array}$ & $\begin{array}{l}\text { ISO } 9000 \\
2005\end{array}$ & $\begin{array}{l}\text { ISO } 9000 \\
2015\end{array}$ & \\
\hline 1 & Definitions & $\mathrm{x}$ & $\mathrm{x}$ & $\mathrm{x}$ & $\mathrm{x}$ & $\mathrm{x}$ & \\
\hline 2 & Quality management principles & - & - & $\mathrm{x}$ & $\mathrm{x}$ & $\mathrm{x}$ & \\
\hline 3 & $\begin{array}{l}\text { Fundamentals for quality } \\
\text { management systems }\end{array}$ & - & - & $\mathrm{x}$ & $\mathrm{x}$ & $\mathrm{x}$ & \\
\hline 4 & $\begin{array}{l}\text { Graphic representation of relations } \\
\text { between terms and definitions }\end{array}$ & - & - & $\mathrm{x}$ & $\mathrm{x}$ & $\mathrm{x}$ & $\begin{array}{l}\text { Table } 1 . \\
\text { Content of successive }\end{array}$ \\
\hline 5 & General information & $\mathrm{x}$ & $\mathrm{x}$ & $\mathrm{x}$ & $\mathrm{x}$ & $\mathrm{x}$ & $\begin{array}{r}\text { revisions of the } \\
\text { terminology }\end{array}$ \\
\hline
\end{tabular}


IJQSS

13,4

A content analysis of successive revisions of the standard, which included the requirements for a quality management system, resulted in the identification of eight key components and these are presented in Table 2 .

As many as 10 components, the highest result, were identified in ISO 9004 and are presented in Table 3.

\section{4}

Table 2.

Content of successive revisions of the standard, including requirements for a quality management system

\begin{tabular}{|c|c|c|c|c|c|c|}
\hline No. & $\begin{array}{l}\text { Label } \\
\text { Year of publication }\end{array}$ & $\begin{array}{c}\text { ISO } 9001 \\
\text { ISO } 9002 \\
\text { ISO } 9003 \\
1987\end{array}$ & $\begin{array}{c}\text { ISO } 9001 \\
\text { ISO } 9002 \\
\text { ISO } 9003 \\
1994\end{array}$ & $\begin{array}{l}\text { ISO } 9001 \\
2000\end{array}$ & $\begin{array}{l}\text { ISO } 9001 \\
2008\end{array}$ & $\begin{array}{l}\text { ISO } 9001 \\
2015\end{array}$ \\
\hline B1 & $\begin{array}{l}\text { Requirements for quality } \\
\text { management systems }\end{array}$ & $\mathrm{x}$ & $\mathrm{x}$ & $\mathrm{x}$ & $\mathrm{x}$ & $\mathrm{x}$ \\
\hline B2 & Definitions & - & $\mathrm{x}$ & - & - & - \\
\hline B3 & $\begin{array}{l}\text { Correspondence between ISO } 9001 \\
\text { and ISO } 14001\end{array}$ & - & - & $\mathrm{x}$ & $\mathrm{x}$ & - \\
\hline B4 & $\begin{array}{l}\text { Relation between the current and } \\
\text { previous version of ISO } 9001\end{array}$ & - & - & $\mathrm{x}$ & $\mathrm{x}$ & - \\
\hline B5 & $\begin{array}{l}\text { Clarification of structure, } \\
\text { terminology and concepts of the } \\
\text { standard }\end{array}$ & - & - & - & - & $\mathrm{x}$ \\
\hline B6 & $\begin{array}{l}\text { Information on other International } \\
\text { Standards on quality management } \\
\text { developed by ISO/TC } 176\end{array}$ & - & - & - & - & $\mathrm{x}$ \\
\hline B7 & Quality management principles & - & - & - & - & $\mathrm{x}$ \\
\hline B8 & General information & $\mathrm{x}$ & $\mathrm{x}$ & $\mathrm{x}$ & $\mathrm{x}$ & $\mathrm{x}$ \\
\hline
\end{tabular}

Notes: International Organization for Standardization = ISO; Technical Committee = TC

Source: Based on ISO 9001:1987, ISO 9001:1994, ISO 9001:2000, ISO 9001:2008 and ISO 9001:2015

\begin{tabular}{|c|c|c|c|c|c|c|}
\hline No. & $\begin{array}{l}\text { Label } \\
\text { Year of publication }\end{array}$ & $\begin{array}{l}\text { ISO } 9004 \\
1987\end{array}$ & $\begin{array}{l}\text { ISO 9004-1 } \\
1994\end{array}$ & $\begin{array}{l}\text { ISO } 9004 \\
2000\end{array}$ & $\begin{array}{l}\text { ISO } 9004 \\
2009\end{array}$ & $\begin{array}{l}\text { ISO } 9004 \\
2018\end{array}$ \\
\hline $\mathrm{C} 1$ & $\begin{array}{l}\text { Guidelines on quality management } \\
\text { and quality management systems }\end{array}$ & $\mathrm{x}$ & $\mathrm{x}$ & $\mathrm{x}$ & $\mathrm{x}$ & $\mathrm{x}$ \\
\hline $\mathrm{C} 2$ & Definitions & - & $\mathrm{x}$ & - & $\mathrm{x}$ & - \\
\hline C3 & $\begin{array}{l}\text { Guidelines for } \\
\text { self-assessment }\end{array}$ & - & - & $\mathrm{x}$ & $\mathrm{x}$ & $\mathrm{x}$ \\
\hline $\mathrm{C} 4$ & $\begin{array}{l}\text { Information on the process for } \\
\text { continual improvement }\end{array}$ & - & - & $\mathrm{x}$ & - & - \\
\hline $\mathrm{C} 5$ & Quality management principles & - & - & - & $\mathrm{x}$ & - \\
\hline C6 & $\begin{array}{l}\text { Correspondence between ISO } 9004 \\
\text { and ISO } 9001\end{array}$ & - & - & - & $\mathrm{x}$ & - \\
\hline $\mathrm{C} 7$ & Guidelines for services & - & $\mathrm{x}$ & - & - & - \\
\hline $\mathrm{C} 8$ & Guidelines for processed materials & - & $\mathrm{x}$ & - & - & - \\
\hline C9 & $\begin{array}{l}\text { Guidelines for quality } \\
\text { improvement }\end{array}$ & - & $\mathrm{x}$ & - & - & - \\
\hline $\mathrm{C} 10$ & General information & $\mathrm{x}$ & $\mathrm{x}$ & $\mathrm{x}$ & $\mathrm{x}$ & $\mathrm{x}$ \\
\hline
\end{tabular}

Table 3.

Content of successive revisions of the ISO 9004 standard

9004:2000, ISO 9004:2009 and ISO 9004:2018 
The analysis presented above demonstrated that some components are assigned to one standard only, e.g. requirements for a quality management system, whereas the remaining ones are present in two and sometimes three documents, e.g. the quality management principles. When the occurrence of repeated components in many standards is omitted, the ISO 9000 series allows the identification of 12 different components (Table 4). However, this number was reduced to 11 , as it was decided to exclude the last component, i.e. general information, from the analysis. This decision was due to strong internal diversification (i.e. it consists of different elements) and had a relatively low factual value.

The questionnaire proposed 11 claims concerning the significance of particular components, e.g. "I find the definitions a significant part of ISO 9000 series of standards and it should be included in the standards." As many as 11 statements referring to the quality of the components' development, e.g. "I find the definitions to be well prepared in ISO 9000 series of standards." The respondents' task was to decide to what extent they agreed with the given statements by selecting one of the choices on the following five-point Likert scale:

- 1 - "not at all,"

- 2 - "rather not,"

- 3 - "neither yes nor not,"

- 4 - "rather yes" and

- 5 - "totally agree."

The results were interpreted according to the following intervals:

- $1 \leq$ results $\leq 3$ - lack of acceptance;

- $3<$ results $\leq 3.5$ - acceptance but with a very low level of recognition;

- $3.5<$ results $\leq 4-$ acceptance but with a low level of recognition;

\begin{tabular}{|c|c|c|c|}
\hline No. & Component & Items & \\
\hline 1 & Definitions & $\mathrm{A} 1, \mathrm{~B} 2, \mathrm{C} 2$ & \\
\hline 2 & Graphic representation of relations between terms and definitions & A4 & \\
\hline 3 & Quality management principles & A2, B7, C5 & \\
\hline 4 & Requirements for quality management systems & $\mathrm{B} 1$ & \\
\hline 5 & $\begin{array}{l}\text { Guidelines explaining (interpreting, exemplifying, etc.) the requirements } \\
\text { for a quality management system }\end{array}$ & $\mathrm{C} 1$ & \\
\hline 6 & $\begin{array}{l}\text { Guidelines related to additional (i.e. not included among requirements for } \\
\text { the system of quality management) activities/solutions connected with } \\
\text { quality management, e.g. concerning benchmarking }\end{array}$ & $\mathrm{C} 1$ & \\
\hline 7 & Self-assessment tool & C3 & \\
\hline 8 & $\begin{array}{l}\text { Guidelines concerning quality management in relation to chosen forms of } \\
\text { activity (e.g. related to services) }\end{array}$ & $\mathrm{C} 7, \mathrm{C} 8$ & \\
\hline 9 & $\begin{array}{l}\text { Guidelines concerning the improvement of an organization including the } \\
\text { description of chosen techniques and tools such as e.g. Pareto chart }\end{array}$ & $\mathrm{C} 4, \mathrm{C} 9$ & \\
\hline 10 & $\begin{array}{l}\text { Description of the relation between chosen standards (e.g. the current and } \\
\text { previous revision of the same standard or between ISO } 9001 \text { and ISO } \\
\text { 14001) }\end{array}$ & $\mathrm{B} 3, \mathrm{~B} 4, \mathrm{C} 6$ & \\
\hline 11 & $\begin{array}{l}\text { Information on other International Standards on quality management } \\
\text { developed by ISO/TC } 176\end{array}$ & B6 & Table 4. \\
\hline 12 & General information & $\mathrm{A} 3, \mathrm{~A} 5, \mathrm{~B} 5, \mathrm{~B} 8, \mathrm{C} 10$ & $\begin{array}{l}\text { Key components of } \\
\text { the ISO } 9000 \text { series of }\end{array}$ \\
\hline \multicolumn{2}{|c|}{ Source: The authors } & & standards \\
\hline
\end{tabular}


IJQSS

13,4
- $4<$ results $\leq 4.5$ - acceptance and an average level of recognition; and

- $4.5<$ results $\leq 5-$ acceptance and a high level of recognition.

\subsection{Sampling}

This research needed to recruit experts with extensive knowledge on quality management. Therefore, the questionnaire described above was sent to researchers who, between January 1, 2015, and the end of July 2018, had published a scientific study on the ISO 9000 series of standards. The study was designed to concern one or more standards from the ISO 9000 family. Thus, the questionnaire was sent to the authors and co-authors of the following:

- An article in one of the leading scientific journals, i.e. International Journal of Quality and Reliability, Total Quality Management and Business Excellence Management or TQM Journal, the journals recognized as the most significant in the area of quality management (Carnerud et al., 2018); and

- An article in the Polish-language scientific journal "Problemy jakości" (The Problems of Quality) or a scientific (refereed) Polish-language monograph.

In this way, the authors compiled an initial list of 231 authors. The next step was to discover these researchers' e-mails and those of 211 experts were identified.

To gather necessary information from respondents, the CAWI method was used. The research questionnaire described in the previous section was available on a website for respondents to complete. The use of CAWI has increased greatly over the past decade, driven partially by technological development and increased internet penetration and partially by falling response rates in traditional modes of polling (Sowa et al., 2015). While some studies have found potential disadvantages to CAWI, e.g. relatively higher levels of "don't know" responses and high levels of break-offs, research has shown many advantages of CAWI compared to traditional modes of polling. This method is cost-efficient, allows automatic correction of errors and omissions during interviews and lessens problems with social desirability bias toward interviewers (Hansen and Pedersen, 2012).

Requests to complete the questionnaire were sent from September until December 2018 and 73 correctly completed questionnaires were received, 45 from Poland and 28 from other countries (Table 5). The entire sample group (73 experts) was dominated by researchers 40 years old or older $(87 \%)$, employed at universities $(92 \%)$ and having dealt with quality management for 10 years or longer $(92 \%)$. Apart from their scientific activities, they had also, in the previous three years, delivered lectures to students (92\%) and carried out professional training sessions on quality management $(66 \%)$ and practical activities, i.e. performing audits, implementing quality management systems, etc. $(62 \%)$.

Cronbach's alpha coefficient was calculated to test the reliability of the latent constructs and the results were as follows: 0.815 (significance of components) and 0.883 (quality of component development). These values indicate acceptable to good reliability.

\subsection{Importance-performance analysis}

The IPA technique offers a novel means to assess people's satisfaction based on a disconfirmation of the expectation paradigm. This paradigm implies that expectations (i.e. perceived importance) that are greater than the provision performance leads to negative disconfirmation, i.e. dissatisfaction, whereas provision performance that is greater than expectation leads to positive disconfirmation, i.e. satisfaction (Hua and Chen, 2019). This business research technique was developed as a marketing tool to examine and suggest 


\begin{tabular}{lrr}
\hline Country & No of respondents & $\begin{array}{r}\text { Quality } \\
\text { management } \\
\text { experts }\end{array}$ \\
Poland & 45 & 3 \\
Malaysia & 3 & \\
Portugal & 3 & $\mathbf{5 1 7}$ \\
Sweden & 3 & \\
Italy & 2 & \\
Spain & 2 & \\
India & 2 & \\
Serbia & 2 & Table 5. \\
Great Britain & 1 & Distribution of \\
Brazil & 1 & respondents by \\
China & 1 & country of origin \\
Finland & 1 & \\
Greece & 1 & \\
Lithuania & 1 & \\
Germany & 1 & \\
Slovenia & & \\
USA & & \\
Source: Own study & & \\
\hline
\end{tabular}

solutions to management decisions. Although initially developed for marketing purposes, its application has been extended to various fields, including, food services, education, banking, public administration, e-business and science (Sever, 2015).

In its typical application, IPA involves assessing different aspects of an organization's features in terms of customer perceptions of performance and importance (significance). Such features are typically represented in a $2 \times 2$ grid, where each quadrant can be divided among specific suggestions. Although the application of IPA has been viewed as simple and intuitive, over the years, several different approaches to inferring priorities and measuring importance have emerged in the literature (Riviezzo et al., 2009). Biesiok and his team proposed one such approach (Biesiok et al., 2016), which typically introduces an additional dividing line set at a $45^{\circ}$ angle to the $x$-axis. This line divides the first and third quarters into two parts, resulting in the following six aspect groups:

- Ia "Keep up" - factors that should be maintained at their current levels;

- Ib "Monitor" - factors that should be monitored, as their degradation requires an immediate reaction;

- II "Concentrate here" - factors that require instant improvement;

- IIIa "Improve if possible" - factors that require improvement if there are free resources;

- IIIb "Low priority" - low priority factors that do not require attention at the moment; and

- IV "Keep status quo" - factors that do not need to be tackled (Figure 1).

This approach can be described as an "expanded IPA."

Another variant of the technique is the "IPA oriented to balance between performance and importance" in which the division into four quarters is insignificant. However, this approach introduces, like the "expanded IPA," a line set at a $45^{\circ}$ angle to the $x$-axis (Dahlgaard-Park and Dahlgaard, 2008; Dahlgaard et al., 2011). This way, the issues 


\section{IJQSS \\ 13,4}

\section{8}

Figure 1.

IPA matrix

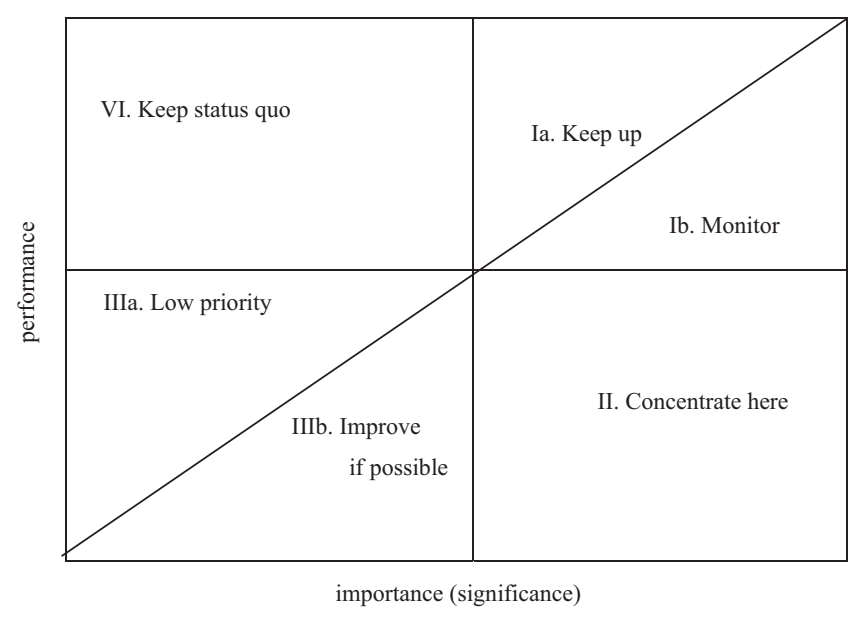

Source: Biesiok et al. (2016)

considered in the study are divided into the following three groups: characterized by equality between importance and performance - points located on or near the line, characterized by higher importance than performance - points located under the line and characterized by higher performance than importance - points located above the line. If importance is significantly higher than performance (Group 2), the issue needs immediate improvement. The opposite situation is taking place - when performance is significantly higher than importance (Group 3) - it means that given issues probably do not require as much attention and/or resources as until now (Eskildsen and Dahlgaard, 1998; Dahlgaard and Dahlgaard-Park, 2004, 2010).

The "expanded IPA" has been chosen for this study because this approach is close to the core version of IPA and more often used in scientific publications compared to the "IPA oriented to balance."

\section{Results}

The average of all grades concerning the significance of separate components was 4.07, indicating, in general, that the expert respondents believed that the ISO 9000 series standards are appropriately constructed, as all the elements they include are important. However, opinions diverged with respect to separate issues. "Requirements for a system of quality management," "quality management principles" and "definitions" were ranked highest, whereas "information on the standards prepared by the committee ISO/TC 176 Managing quality and maintaining quality” was ranked least important (Table 6).

The average of all grades concerning the quality of specific components was 3.63, indicating that the experts evaluated the ISO 9000 series standards to have been properly written, in general. Still, opinions as to the quality level of specific components diverged. The highest rankings were given to "quality management principles," "requirements for quality management systems," and graphic presentations of the relations between terms and definitions, whereas "the guidelines concerning quality management in specific situations" were awarded the lowest grades (Table 7). 


\begin{tabular}{|c|c|c|c|}
\hline No & Components & Average & SD \\
\hline 1. & Requirements for quality management systems & 4.64 & \\
\hline 2. & Quality management principles & 4.59 & 0.5 \\
\hline 3. & Definitions & 4.55 & 0.75 \\
\hline 4. & $\begin{array}{l}\text { Guidelines explaining (interpreting, exemplifying, etc.) the requirements } \\
\text { for a quality management system }\end{array}$ & 4.33 & 0.99 \\
\hline 5. & Self-assessment tool & 4.12 & 1.05 \\
\hline 6. & Guidelines concerning improvement of an organization & 3.99 & 0.5 \\
\hline 7. & $\begin{array}{l}\text { Guidelines concerning quality management in relation to chosen forms of } \\
\text { activity }\end{array}$ & 3.97 & 1.04 \\
\hline 8. & $\begin{array}{l}\text { Guidelines related to additional (i.e. not included among requirements for } \\
\text { the system of quality management) activities/solutions connected with } \\
\text { quality management }\end{array}$ & 3.89 & 1.03 \\
\hline 9. & Description of the relation between chosen standards & 3.78 & 1.2 \\
\hline 10. & Graphic representation of relations between terms and definitions & 3.63 & \\
\hline 11. & $\begin{array}{l}\text { Information on other international standards on quality management } \\
\text { developed by ISO/TC } 176\end{array}$ & 3.30 & 1.25 \\
\hline
\end{tabular}

Source: Own study

management

experts

519

Table 6.

Evaluation of significance

\begin{tabular}{clcc}
\hline No & Components & Average & SD \\
\hline 1. & Quality management principles & 4.27 & 0.89 \\
2. & Requirements for quality management systems & 4.04 & 0.87 \\
3. & Graphic representation of relations between terms and definitions & 3.71 & 1.03 \\
4. & Description of the relation between chosen standards & 3.71 & 0.89 \\
5. & Definitions & 3.68 & 1.32 \\
6. & Self-assessment tool & 3.58 & 1.12 \\
7. & Information on other international standards on quality management & 3.45 & 1.12 \\
& developed by ISO/TC 176 & 3.44 & 1.04 \\
8. & Guidelines explaining (interpreting, exemplifying, etc.) the requirements & & \\
& for a quality management system & 3.21 & 1.07 \\
9. & Guidelines related to additional (i.e. not included among requirements for & & \\
& the system of quality management) activities/solutions connected with & & \\
10. & quality management & 3.21 & 1.14 \\
11. & Guidelines concerning the improvement of an organization & 3.10 & 1.13 \\
& activity concerning quality management in relation to chosen forms of & &
\end{tabular}

Source: Own study

Table 7.

Evaluation of standards elaboration

The IPA was used to evaluate all components simultaneously in reference to both criteria used in the research (Figure 2).

Based on the results shown in Figure 2, the components included in ISO 9000, ISO 9001 and ISO 9004 were divided into six groups (Table 8).

\section{Discussion}

The first research question (RQ1) asked whether the ISO 9000 family of standards was a generally accepted part of the quality management concept. Study findings indicated that they are widely accepted, thereby confirming the positive opinions concerning the standards 


\section{IJQSS \\ 13,4}

Figure 2.

IPA for key

components of the ISO 9000 family of standards

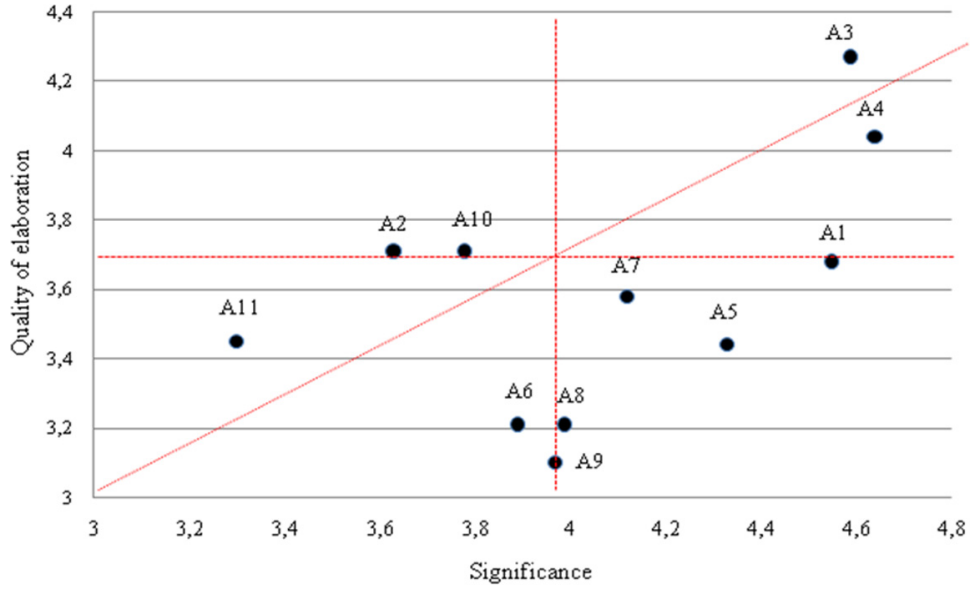

Source: Own study
Quadrant IV

Keep status quo:

A2 - Graphic representation of relations between terms and definitions

A10 - Description of the relation between chosen standards

Quadrant III

Low priority (IIIa):

A11 -Information on other International

Standards on quality management developed by

ISO/TC 176

Improve if possible (IIIb):

A6 - Guidelines related to additional (i.e. not included among requirements for the system of

Table 8.

IPA Matrix for key components of the ISO 9000 series of standards quality management) activities/solutions

connected with quality management

A9 - Guidelines concerning the improvement of an organization

Source: Own study
Quadrant I

Keep up (Ia):

A3 - Quality management principles

Monitor (Ib):

A4 - Requirements for quality management systems

Quadrant II

Concentrate here:

A1 - Definitions

A5 - Guidelines explaining the requirements for a quality management system

A7 - Self-assessment tool

A8 - Guidelines concerning quality management in relation to chosen forms of activity

that have appeared in the scientific literature (Fonseca and Domingues, 2017; Gaspar et al., 2018). Study results also indicated differing assessments of the two dimensions. Rated higher was the significance of the components included in the standards and the scores related to the significance of the separate components was 4.07, indicating that the experts assessed the ISO 9000 family of standards as including significant elements.

However, the respondents' assessment of the quality of the standards' elaboration (i.e. their correctness, relevance to current trends in quality management, comprehensibility, etc.) was not as certain. The average score here was 3.63, indicating that, although the quality of the standards was judged acceptable (i.e. it was greater than 3), it was not evaluated high, i.e. four or greater. Therefore, the experts can be assumed to, in general, accept the standards of ISO 
9000 series but rate as low or merely average their usefulness in clarifying the essence of quality management, creating a terminology order, providing a competitive advantage, etc.

This finding is in accordance with the results of research carried out by Gutiérrez et al. (2010), who dealt primarily with the ISO 9001 standard. The authors showed that, on the basis of the ISO 9000 family, an organization can make the initial step only in fully implementing quality management. However, the expectations of the experts who participated in the current study might have been too high. Also, worth noting are the nature of the standards, the goals of standardization (i.e. to publish specifications for common and repeated use, aimed at achieving an optimum degree of order or uniformity in a given context, discipline or field) and, finally, the rules of standards development elaboration (e.g. development of standards through a multistakeholder process and on the basis of a consensus). Under these assumptions, ISO 9000 standards cannot be expected to include highly innovative or unique solutions fully adjusted to every organization's needs. What may be expected from them is to be appropriately elaborated on the basis of current knowledge.

The second research question $(R Q 2)$ was formulated as follows: Which components of the ISO 9000 family of standards are the most significant? The research allowed the identification of the five most significant components of the ISO 9000 family of standards. The first place in the chart was given, not surprisingly, to "the requirements for the quality management system." The next places in the chart were as follows:

- Quality management principles;

- Definitions;

- Guidelines explaining (interpreting, exemplifying, etc.) the requirements for a quality management system; and

- Self-assessment tool.

The opinions on the significance of the last two components above were much more diverse than those related to the previous three components (as shown by the higher standard deviation values). The scores given to the five components above (which were higher than 4 in every case) indicate that, in the expert opinions, they constitute the core of the ISO 9000 family of standards. Thus, it seems reasonable to assume that experts in quality management recommend that the components be used to design or review standards concerning other fields (e.g. energy management or human resources).

The third research question $(R Q 3)$ was designed to establish which components of the ISO 9000 family of standards are elaborated best. Generally speaking, the quality of the ISO 9000 family of standards elaboration was not evaluated high. The experts who participated in the research assessed "quality management principles" as having the highest level of elaboration (average score 4.27). Given that they were ranked as the second most significant component, it can be claimed that they are the strength of the ISO 9000 family of standards. The next most highly ranked component with respect to quality was "the requirements for quality management systems" with an average score of 4.04, meaning that the experts accepted the way in which it expressed requirements. However, in their assessments, they pointed out that they see the quality management system as a "mediocre" solution at best.

The next places in the chart were as follows:

- Graphic representation of relations between terms and definitions;

- Description of the relation between chosen standards;

- Definitions; and

- Self-assessment tool. 
IJQSS

13,4

They were all evaluated with scores of less than 4, indicating that, although their level was judged acceptable, they received low or very low recognition among the experts.

The last research question (RQ4) was: Which components of the ISO 9000 family of standards should be improved first? The IPA helped identify these components, which were characterized by both relatively high significance and low elaboration quality. This group included the following four factors:

(1) Definitions;

(2) Guidelines explaining the requirements for a quality management system;

(3) Self-assessment tool; and

(4) Guidelines concerning quality management in relation to chosen forms of activity.

An apparent contradiction is noticeable in the case of two components, i.e. "definitions" and "self-assessment tool." Both were included in the best-elaborated factors and also in those which should be improved first. This situation has a logical explanation. Although the quality of elaboration of the two components is higher than the rest, it is still noticeably lower than the quality of elaboration of the quality management principles. The scientific literature provides some signals that serve to confirm this interpretation. Among others, Anttila and Jussila (2017) note the general ambiguity of many fundamental concepts and definitions included in the standards. The low quality of definitions was also pointed out by Olsen and Borit (2013). On the other hand, Bendell (2000) focused attention on problems related to the self-assessment tool.

\section{Conclusions}

The ISO 9000 family of standards has existed for over 30 years. During this time, it has become a part of the quality movement and has been identified as one of the most important international standards. The research reported herein demonstrated that it has gained the acceptance of experts dealing with quality management. However, this positive view refers primarily to the general idea of developing quality management standards and the content structure of the standards (i.e. the components included in them). The quality of the standards' elaboration was rated noticeably lower. Therefore, it is essential to improve four aspects of the standards, i.e. definitions, guidelines explaining the requirements for a quality management system, the self-assessment tool and guidelines concerning quality management in relation to chosen forms of activity. It might also be reasonable to consider removing those components from the standards whose significance was ranked lowest.

Future research should be oriented primarily on directions and possible ways of improving the four components. So far, little attention has been paid to them. Therefore, it is crucial to establish the weaknesses of each component, the expectations of the users of the standards concerning these components and the opportunities that exist to meet those expectations. It should also be noted that choosing another version of the IPA technique (e.g. "IPA oriented to balance") could lead to slightly different conclusions of the study because it puts more emphasis on the difference in the assessment of importance and performance. Therefore, it would be worth carrying out such research and comparing the results.

The research reported here has both practical and societal implications. It points the way to improve the standards, the applicability of which is not strictly limited to quality management, which may be successfully used to improve the standards in other management areas. The research conclusions can be directly used to increase the 
effectiveness of standardization organizations and improve the standards' overall quality. A significant implication for managers is identifying and pointing out the components of the ISO 9000 family of standards (other than requirements for a quality management system) that may become interesting and useful to them in managing their organizations.

\section{Quality management experts}

\section{References}

Anttila, J. and Jussila, K. (2017), "ISO 9001: 2015 - a questionable reform: what should the implementing organisations understand and do?", Total Quality Management and Business Excellence, Vol. 28 Nos 9/10, pp. 1090-1105.

Bendell, T. (2000), "The implications of the changes to ISO 9000 for organisational excellence", Measuring Business Excellence, Vol. 4 No. 3, pp. 11-14.

Biesiok, G., Wyród - Wróbel, J. and Ś więtek - Bysko, A. (2016), “,wykorzystanie analizy IPA w badaniach satysfakcji z opakowań kosmetyków”, Marketing i Rynek, No. 7, pp. 18 -29.

Boiral, O. (2012), "ISO 9000 and organizational effectiveness: a systematic review", Quality Management Journal, Vol. 19 No. 3, pp. 16-37.

Carnerud, D., Jaca, C. and Bäckström, I. (2018), "Kaizen and continuous improvement - trends and patterns over 30 years", The TQM Journal, Vol. 30 No. 4, pp. 371-390.

Casadesus, M. and Gimenez, G. (2000), "The benefits of the implementation of the ISO 9000 standard: empirical research in 288 Spanish companies", The TQM Magazine, Vol. 12 No. 6, pp. $432-441$.

Casadesus, M. and Karapetrovic, S. (2005), "Has ISO 9000 lost some of its lustre? A longitudinal impact study", International Journal of Operations and Production Management, Vol. 25 No. 6, pp. 580-596.

Cort, G. (2010), "Chair's technical message: the ISO 9000 ecosystem”, available at: https://isotc.iso.org/ livelink/livelink/fetch/-8835176/8835194/8835203/N993_-_Chairs_Technical_Message\%2C_The_ ISO_9000_Ecosystem.pdf?nodeid=9492775\&vernum $=-2$

Dahlgaard, J.J. and Dahlgaard-Park, S.M. (2004), "The 4P quality strategy for breakthrough and sustainable development”, European Quality, Vol. 10 No. 4, pp. 6-19.

Dahlgaard-Park, S.M. and Dahlgaard, J.J. (2010), "Organizational learnability and innovability a system for assessing, diagnosing and improving innovations", International Journal of Quality and Service Sciences, Vol. 2 No. 2, pp. 153-174.

Dahlgaard-Park, S.M. and Dahlgaard, J.J. (2008), "A strategy for building sustainable innovation Excellence - A danish study”, in: Zink, K.J. (Ed.), Corporate Sustainability as a Challenge for Comprehensive Management, Physica - Verlag, Heidelberg, pp. 77-94.

Dahlgaard, J.J., Pettersen, J. and Dahlgaard-Park, S.M. (2011), "Quality and lean health care: a system for assessing and improving the health of health care organisations”, Total Quality Management and Business Excellence, Vol. 22 No. 6, pp. 673-689.

Eskildsen, J. and Dahlgaard, J. (1998), “A practical diagnosis of business excellence”, Measuring Business Excellence, Vol. 2 No. 4, pp. 24-28.

Fonseca, L. and Domingues, J.P. (2017), "ISO 9001: 2015 edition-management, quality and value", International Journal of Quality Research, Vol. 1 No. 11, pp. 149-158.

Fonseca, L.M., Domingues, J.P., Machado, P.B. and Calderón, M. (2017), "Management system certification benefits: Where do We stand?", Journal of Industrial Engineering and Management, Vol. 10No No. 3, pp. 476-494.

Gaspar, M.L., Popescu, S.G., Dragomir, M. and Unguras, D. (2018), "Defining strategic quality directions based on organisational context identification; case study in a software company", Procedia - Social and Behavioral Sciences, No. Vol. 238, pp. 615-623.

Gotzamani, K. (2010), "Results of an empirical investigation on the anticipated improvement areas of the ISO 9001: 2000 standard”, Total Quality Management and Business Excellence, Vol. 21 No. 6, pp. 687-704. 
IJQSS

13,4

Gutiérrez, L.J.G., Torres, I.T. and Molina, V.B. (2010), "Quality management initiatives in Europe: an empirical analysis according to their structural elements", Total Quality Management and Business Excellence, Vol. 21 No. 6, pp. 577-601.

Hallström, K.T. (2004), Organizing International Standardization: ISO and the IASC in Quest of Authority, Edward Elgar, Cheltenham-Northampton.

Hansen, K., M. and Pedersen, R., T. (2012), "Efficiency of different recruitment strategies for web panels", International Journal of Public Opinion Research, Vol. 24 No. 2, pp. 238-249.

Hoel, T. and Chen, W. (2018), "Interaction between standardisation and research: a case study", International Journal of Standardization Research, Vol. 16 No. 1, pp. 22-38.

Hua, J. and Chen, W.Y. (2019), "Prioritizing urban rivers' ecosystem services: an importanceperformance analysis", Cities, Vol. 94, pp. 11-23.

Kafel, P. and Nowicki, P. (2014), "Functioning of environmental and quality management systems after registration of management standard certification: Case study of polish organizations", International Journal for Quality Research, Vol. 8 No. 4, pp. 505-516.

Karapetrovic, S., Fa, M.C. and Saizarbitoria, I.H. (2010), "What happened to the ISO 9000 luster? An eight-year study", Quality Control and Applied Statistics, Vol. 55 No. 3, pp. 227-228.

Manders, B., de Vries, H.J. and Blind, K. (2016), "ISO 9001 and product innovation: a literature review and research framework", Technovation, Vols 48/49, pp. 41-55.

Olsen, P. and Borit, M. (2013), "How to define traceability", Trends in Food Science and Technology, Vol. 2 No. 29, pp. 142-150.

Riviezzo, A., Nisco, A. and Napolitano, M., R. (2009), "Importance-performance analysis as a tool in evaluating town Centre management effectiveness", International Journal of Retail and Distribution Management, Vol. 37 No. 9, pp. 748-764.

Sampaio, P., Saraiva, P. and Guimarães, R.A. (2009), "ISO 9001 certification research: questions, answers and approaches", International Journal of Quality and Reliability Management, Vol. 26 No. 1, pp. 38-58.

Saraiva, M., Novas, J.C., Ferreira, O. and Pires, A.R. (2017), "ISO 9001 quality management systems: Literature review", TMQ - Techniques, Methodologies and Quality, No. 8, pp. 11-43.

Seddon, J. (1997), In Pursuit of Quality: The Case against ISO 9000, Oak Tree Press, Dublin.

Seddon, J. (2000), The Case against ISO 9000, Oak Tree Press, Dublin.

Serhan, H. and Kabèche, D. (2017), "Analysis of ISO 9001 paradox of knowledge codification using the activity system model: Tensions in practices and expansive learning”, International Journal of Standardization Research, Vol. 15 No. 2, pp. 37-56.

Sever, I. (2015), “Importance-performance analysis: a valid management tool?”, Tourism Management, No. Vol. 48, pp. 43-53.

Sowa, P., Pędziński, B., Krzyżak, M., Maślach, D., Wójcik, S. and Szpak, A. (2015), “The Computer-Assisted web interview method as used in the national study of ICT use in primary healthcare in Poland reflections on a case study", Studies in Logic, Grammar and Rhetoric, Vol. 43 No. 1, pp. 137-146.

Spring, B., M. (2016), "Standards management in the Twenty-First century: architectural challenges and management opportunities", International Journal of Standardization Research, Vol. 14 No. 1, pp. 34-44.

Tarí, J.J., Molina-Azorín, J.F. and Heras, I. (2012), "Benefits of the ISO 9001 and ISO 14001 standards: a literature review", Journal of Industrial Engineering and Management, Vol. 5 No. 2, pp. 297-322.

Urban, W. (2012), "ISO 9001 as a tool for supporting strategic advantages", Transformations in Business and Economics, Vol. 3 No. 11, pp. 57-71.

West, J. (2007), "Using the whole ISO 9000 family of quality management system standards", Quality Engineering, No. 19, pp. 385-392.

Wright, J.D. and Marden, P.V. (2010), "Survey research and social science: history, current practice, and future prospects", in: Marsden, P.V. and Wright, J.D. (Eds), Handbook of Survey Research, Emerland, Bingley. 


\section{Further reading}

International Organization for Standardization (1986), ISO 8402: Quality - Vocabulary, ISO, Geneva.

International Organization for Standardization (1987), ISO 9001: Quality Systems - Model for Quality Assurance in Design/Development, Production, Installation and Servicing, ISO, Geneva.

International Organization for Standardization (1987), ISO 9004: Quality Management and Quality System elements - Guidelines, ISO, Geneva.

International Organization for Standardization (1991), ISO 9004: Quality Management and Quality System Elements - Part 2: Guidelines for Services, ISO, Geneva.

International Organization for Standardization (1993), ISO 9004: Quality Management and Quality System Elements - Part 3: Guidelines for Processed Materials, ISO, Geneva.

International Organization for Standardization (1993), ISO 9004: Quality Management and Quality System Elements - Part 4: Guidelines for Quality Improvement, ISO, Geneva.

International Organization for Standardization (1994), ISO 8402: Quality Management and Quality assurance- Vocabulary, ISO, Geneva.

International Organization for Standardization (1994), ISO 9001: Quality Systems - Model for Quality Assurance in Design/Development, Production, Installation and Servicing, ISO, Geneva.

International Organization for Standardization (1994), ISO 9004-1: Quality Management and Quality System Elements - Part 1: Guidelines, ISO, Geneva.

International Organization for Standardization (2000), ISO 9000: Quality Management systems Fundamentals and Vocabulary, ISO, Geneva.

International Organization for Standardization (2000), ISO 9001: Quality Management Systems Requirementns, ISO, Geneva.

International Organization for Standardization (2000), Quality Management Systems - Guidelines for Performance Improvements, ISO, Geneva.

International Organization for Standardization (2005), ISO 9000: Quality Management systems Fundamentals and Vocabulary, ISO, Geneva.

International Organization for Standardization (2008), ISO 9001 Quality Management Systems Requirements, ISO, Geneva.

International Organization for Standardization (2009), ISO 9004: Managing for the Sustained Success of an Organization - a Quality Management Approach, ISO, Geneva.

International Organization for Standardization (2015), ISO 9000: Quality Management systems Fundamentals and Vocabulary, ISO, Geneva.

International Organization for Standardization (2015), ISO 9001: Quality Management Systems Requirements, ISO, Geneva.

www.iso.org

\section{Corresponding author}

Piotr Rogala can be contacted at: p.rogala@interia.pl

For instructions on how to order reprints of this article, please visit our website:

www.emeraldgrouppublishing.com/licensing/reprints.htm

Or contact us for further details: permissions@emeraldinsight.com 